\title{
CHARTING SOUTH AFRICA'S GLOBAL MARITIME FOREIGN POLICY AND ITS GLOBAL AND REGIONAL MEMBERSHIPS IN THE MARITIME REALM
}

\author{
Vishal Surbun ${ }^{1}$ \\ University of KwaZulu-Natal
}

\begin{abstract}
South Africa's re-entry into the international arena has led to the ratification of several global and regional maritime instruments. In addition, South Africa has been admitted to various international institutions and fora in the maritime space. A key consideration in this regard is whether there is an underlying global maritime foreign policy that underscores South Africa's contributions, interactions and responsibilities in these fora. South Africa does not have a global maritime foreign policy which is contained in an explicit policy document. This article therefore charts how various domestic and continental policy documents and ministerial statements thread together a foundational base for a global maritime foreign policy. What emerges is the primacy of African interests as the golden thread of this foundational base. The article then considers South Africa's practical engagement through a description and categorisation of its membership of global and regional organisations in the maritime realm. The article finally narrows the focus to one organisation, the Indian Ocean Rim Association (IORA) as a platform to consolidate the foundations for a global maritime foreign policy for South Africa. The article concludes by pointing out nuanced factors that should be acknowledged for South Africa to exercise strategic power and influence over policy in the global and regional maritime realm.
\end{abstract}

\section{Background}

Despite the oceans being prominently acknowledged as one of the natural features of the country in the national anthems of pre- and post-apartheid South Africa, the maritime realms of South Africa historically did not receive any significant attention in domestic policy as an economic resource. The legislative framework was sparse and scattered. Prior to 1994, South Africa did not have a national maritime policy. Du Plessis comments:

[Due to] the localized nature of South Africa's maritime values, the absence of an overt maritime threat and South Africa's limited maritime capabilities, a national maritime policy aimed at the realization of hegemonistic political objectives is considered a luxury which South Africa can ill afford. ${ }^{2}$ 
On the international area, South Africa's apartheid era policies and relations were influenced by ideological conflicts of the Cold War era and the consequences of the administration of apartheid policies. From an ideological perspective, erstwhile Prime Minister Vorster remarked in 1977:

It is the grand strategy of the Soviets ultimately to control the southern tip of Africa, well knowing that if they control they Southern tip of Africa, then they not only straddle the Cape sea route, then not only have they got a terrific advantage in the case of a conventional war because then they will be controlling Africa, but they can cut the lifeline of Europe: 24000 ships passing round the Cape, carrying two thirds of Europe's oil, much of its food and other necessaries. ${ }^{3}$

South Africa's key maritime strategy was the protection of the Cape Sea Route, ${ }^{4}$ a chokepoint significant to global and particularly Western shipping. However, Western powers persistently refused to cooperate with South Africa in maritime matters. ${ }^{5}$ This affected South Africa's maritime strategic outlook, and South Africa renounced its position as defender of the Cape Sea Route as a "counterreaction to Western misappreciation of South Africa's maritime importance". ${ }^{6}$ A report prepared by the US Institute for Foreign Policy Analysis in 1981 noted South Africa's position:

If they [Western powers] insisted on isolating and embargoing the Republic of South Africa, Pretoria would no longer devote any of its budget to them ... [n]o longer is security of international shipping rounding the Cape of Good Hope a major concern of South Africa. ${ }^{7}$

The consequence of this policy was that it was no longer a priority to develop any substantial operational capability at sea.

During that period, the credentials of the government had not been accepted in certain United Nations meetings. ${ }^{8}$ As a result, South Africa was precluded from participation in the third United Nations Conference on the Law of the Sea from 1974 to 1982 (UNCLOS III). ${ }^{9}$ Accordingly, the South African government exerted no influence in the development of the most important source of the international law of the sea. ${ }^{10}$ Devine highlights the unique problems that would have arisen for the government's ratification of UNCLOS, namely whether the then purported independent homelands of Transkei, Bophuthatswana, Venda and Ciskei could ratify UNCLOS and whether the landlocked Bophuthatswana and Venda would have access right to the sea through South Africa. ${ }^{11}$ Questions also arose over South Africa's administration of South West Africa (Namibia), namely whether South African could claim the 200 nautical mile exclusive economic zone on behalf of South West Africa and whether South Africa would be entitled to grant mineral concessions in the continental shelf off the territory. ${ }^{12}$

Although government involvement in global legislative developments during this period was negligible due to international isolation, liberation movements did voice concerns over the maritime commons and domestic maritime domain. The African National Congress (ANC) and the Pan-African Congress of Azania both participated as lib- 
eration movements in UNCLOS III, although they were not eligible to sign the treaty. ${ }^{13}$ Oliver Tambo, speaking in Mozambique in 1993, commented:

In the Indian Ocean, we see Pretoria is deeply enmeshed in conspiracies against the Seychelles, in pursuance of the regime's expansionist and aggressive designs against Africa, and in aid of imperialism's global strategy for war. The ANC adds it voice to those of Mozambique and other littoral States in demanding that the Indian Ocean be declared a zone of peace - free of foreign military and naval bases, nuclear arms and other instruments of war that endanger peace and security. ${ }^{14}$

South Africa's re-entry into the international area after 1994, marked a significant sea change in approach and, when South Africa began to redefine its position internationally and on the Continent, Minister Molewa remarked, "[a]s a continent, Africa has largely been focusing on the terrestrial environment to enhance our economic prosperity and neglected significant resources that are available on our shores." 15 This recognition was a move away from sea blindness. A consequence of this sea blindness was that "stakeholders misunderstand or fail to realise the economic importance of Africa's seas and oceans and the contribution they do and can make to development and prosperity". ${ }^{16}$

\section{Objective of the article}

In stark contrast to this historical context, South Africa's re-entry into the international arena has led to the ratification of several global and regional maritime instruments, with their associated rights and obligations. In addition, South Africa has been admitted to various international institutions and fora in the maritime space. The line of enquiry that arises from this admission is: what is the underlying global maritime foreign policy that underscores South Africa's contributions, undertakings and interactions in these fora? South Africa does not have an explicit policy document that sets out its global maritime foreign policy.

The article firstly examines how various domestic and continental policies and ministerial statements provide a foundation for a global maritime foreign policy. The ubiquitous primacy of African interests appears as the golden thread that weaves through South Africa's foreign policy.

The article secondly provides a description and categorisation of South Africa's membership of global and regional organisations. The description highlights some of the contributions of South Africa in these fora. The contributions are inherently varied and scattered across various disciplines and geographic regions. Whilst the description of South Africa's memberships of these organisations provide a useful indication of the reach of the state's participation in these global and regional fora, the scope of the study on which this article reports precluded a more probative analysis of each respective membership. In some instances, the contributions are specialised due to the technical requirements and geographic application of the organisations. As a result, in order to provide a holistic appraisal of how the foundations of a global maritime foreign policy for South Africa is shaped and applied in practice, an organisation with a wide platform must be selected. 
The article then turns to evaluate how South Africa's global maritime policy trends are articulated through the Indian Ocean Rim Association (IORA). Minister Pandor commented, "IORA provides us with a unique opportunity to enhance the spirit of multilateralism within one of the most diverse regions of the world, comprising a heterogeneous mix of developed countries, developing countries, Small Island States, and Least Developed Countries". ${ }^{17}$ IORA accordingly holds particular importance for widespread maritime engagement, which is an opportunity not readily offered in other platforms. The article concludes by pointing out nuanced factors that should be acknowledged for South Africa to exercise strategic power and influence over global policy through the formulation and implementation of a global and regional maritime policy.

\section{Key points from domestic policies underscoring foreign policies and memberships}

In the global maritime space, there is an interrelationship between maritime policy, defence policy and foreign policy. Fougstedt et al. describe a national maritime policy as the "rules governing the use of the means (maritime power) to meet the national needs (maritime [interest])". ${ }^{18}$ They describe national maritime interests as maritime defence, seaborne trade and the exploitation of marine resources. ${ }^{19}$ Singh describes maritime power as "the ability of the nation to use the seas to safeguard and progress its national interests". ${ }^{20}$ Linked to maritime power is maritime strategy, which constitutes a subcomponent of the general military strategy of the South African National Defence Force (SANDF) ${ }^{21}$ and is guided by defence policy. Foreign policy is described as a "multidimensional set of policies, objectives, principles, strategies and plans which cannot be easily packaged into a neatly described formula". ${ }^{22}$ A national maritime policy cannot operate in a domestic vacuum because it operates at sea, most of which extends beyond the jurisdiction and sovereignty of the littoral states. This extraterritorial characteristic of maritime policy is thus inextricably linked to foreign policy and defence policy to constitute a global maritime foreign policy.

To flesh out the key drivers of our global maritime foreign policy, the starting point is reference to the National Development Plan (NDP) 2030, formulated by the National Planning Commission in $2012^{23}$ under the Ministry in the Presidency. The NDP recognises that the decisions and actions taken by the government to "create or modify linkages, regulate and incentivize behavior and adopt policies on global issues are greatly important". ${ }^{24}$ Foreign relations, according to the NDP, "must be driven by the country's domestic economic, political and social demands, as well as our regional, continental and global obligations". ${ }^{25}$ The NDP provides four objectives to guide the formulation of foreign policy, namely to -

- focus on what is practically achievable without over-committing to regional and continental integration;

- remain an influential member of the international community;

- deepen integration with Brazil, Russia, India and China as part of the BRICS group; and 
- to stabilise the regional political economy through increased integration and cooperation and informing the public about the benefits of foreign collaboration, which might help alleviate the xenophobia that countries often experience when their borders are opened. ${ }^{26}$

The NDP notes that articulating South Africa's national interests is a priority to serve as a basis for foreign relations, ${ }^{27}$ and provides some guidance on the objectives of foreign policymaking to reposition South Africa in the region and in the world, namely to:

- expand regional, continental and African trade based on informed understanding of the geopolitics of Africa;

- develop a healthy consultative and practical relationship with South Africa's research and corporate institutions in order to deploy the country's foreign service more effectively in the pursuit of expanded trade and investment; and

- improve the country's leadership role in regional and global affairs. ${ }^{28}$

Of particular relevance to the oceans economy is how the NDP recognises that minerals underpin the economic strength of many countries and observes how "[m]ost African countries have not used their commodity wealth to reduce poverty. The proceeds of oil or minerals extraction have largely been consumed, rather than invested in people and infrastructure." ${ }^{29}$ The NDP further notes, "there may be a gap between the actual endowments and what has been identified and exploited. Sustainable reserves could yet be found" ${ }^{30}$ The NDP also notes that South Africa's membership of BRICS "is an important opportunity to and recognition of its role in the economically emerging African continent". ${ }^{31}$ The NDP further recognises the threat of transnational crimes, particularly piracy, and how this places the coasts and ports of the continent under increasing pressure. The approach to piracy should be "shaped by our own priorities and expectations, as well as those of our regional partners". ${ }^{32}$ This would include strengthening the country's anti-piracy operations and defence force in order for operations to be sustained. ${ }^{33}$

Holistically, the National Planning Commission is of the view that:

South Africa's foreign relations and diplomacy must be informed by the strategic interplay between political, economic, security, environmental and human dynamics. Positioning South Africa in the world must start with establishing greater efficiency (and effectiveness) in regional regimes and institutions; in the country's multiple international affiliations, especially in the BRICS and the global south; in multilateral relations; and in the institutions of global governance. ${ }^{34}$

The second point of reference is a precursor to the White Paper on South Africa's foreign policy, namely the Foreign Policy for South Africa Discussion Document, drawn up in 1996 (the discussion document). ${ }^{35}$ The discussion document reflects the nascent and burgeoning foreign policy of the new democratic government. The discussion document cites Minister Nzo's broad articulation in 1995 of South Africa's foreign policy principles, namely a commitment to - 
- the promotion of human rights;

- the promotion of democracy;

- justice and international law in the conduct of relations between nations;

- international peace and internationally agreed-upon mechanisms for the resolution of conflicts;

- the interests of Africa in world affairs; and

- economic development through regional and international cooperation in an interdependent world. ${ }^{36}$

Of relevance to this article is the importance of multilateralism and its focus on global issues. The discussion document recognises that "[w] ith the growing complexity of international interaction in almost every sphere of human life, the role of multilateral organizations in reconciling and harmonizing the frequently conflicting interests of countries will necessarily increase." ${ }^{37}$ The discussion document elaborates, "[g]lobal issues have domestic relevance and the role that South Africa seeks to play in the development of international thinking in these areas must be related no only to our international objectives but also to our domestic policies. ${ }^{38}$ In other words -

The Government's foreign policy objectives in the multilateral field are to ensure that South Africa plays a role commensurate with its status and abilities in respect of global issues which preoccupy the world today and which are at the same time of major national concern. ${ }^{39}$

However, the wide range of these foreign policy principles has a narrower focus. Minister Nzo commented, "[i]n terms of foreign policy, Africa is clearly to be a priority in the years ahead." ${ }^{40} \mathrm{He}$ went on to say:

The promotion of economic development of the Southern African region is of paramount importance as the economics of the countries in the region are intertwined to such an extent that, for South Africa to believe that it could enter a prosperous future in isolation without taking neighbouring countries with her, would be unrealistic and hazardous. ${ }^{41}$

The African focus is not exclusively linked with economic development, as the discussion document also notes that particular attention will have to be given to measures to "prevent conflict; the monitoring of events; becoming involved in concerted preventative diplomacy; and ways to influence the emergence of a constructive new order on the continent in a positive and significant manner". ${ }^{42}$

The third reference point is the White Paper on South Africa's Foreign Policy, drafted by the Ministry of International Relations and Cooperation and approved by Cabinet on 5 December 2012. ${ }^{43}$ This White Paper supersedes the 1996 discussion document. Wheeler notes that, unlike White Papers issued by other departments of state, this White Paper will not lead to the introduction and adoption of new legislation to guide its implementation. ${ }^{44}$ The policy accords central importance to: 
- our immediate African neighbourhood and continent;

- working with countries of the South to address shared challenges of underdevelopment;

- promoting global equity and social justice;

- working with countries of the North to develop a true and effective partnership for a better world; and

- doing our part to strengthen the multilateral system, including its transformation, to reflect the diversity of our nations and ensure its centrality in global governance. ${ }^{45}$

The policy states that South Africa is a strong proponent of multilateralism as a necessary intergovernmental response to managing globalisation and the deepening interdependence of national economies. ${ }^{46}$ It intends to use membership of BRICS, for example, as a strategic opportunity to advance the interests of Africa in global issues, such as global governance and international trade. ${ }^{47}$ These objectives do not detract from the articulation of the policy of the state's national interests, which embraces:

- the development and upliftment of our people;

- stability of the Republic and the constitutional order;

- growth and development of the South African economy;

- growth and development of Southern Africa;

- a stable and prosperous African continent; and

- a just and equitable world order. ${ }^{48}$

This is further confirmed in the opening lines of the policy, which states that international engagement is based on two central tenets, namely "Pan-Africanism and South-South solidarity. South Africa recognises itself as an integral part of the African continent and therefore understands its national interest as being intrinsically linked to Africa's stability, unity and prosperity." ${ }^{49}$ This notion is stated in the policy in the following definitive terms:

Its [South Africa's] destiny is inextricably linked to that of the Southern Africa region. Regional and continental integration is the foundation of Africa's socio-economic development and political unity, and essential for our own prosperity and security. Consequently, Africa is at the centre of South Africa's foreign policy. South Africa must therefore continue to support regional and continental processes to respond to and resolve crises, strengthen regional integration, significantly increase intra-African trade and champion sustainable development and opportunities in Africa. ${ }^{50}$

The fourth reference point is the Revised White Paper on National Transport Policy drafted by the Department of Transport in 2017. ${ }^{51}$ This policy addresses maritime transport issues relating to economic principles, trade and cargoes, ship financing and registration, the operation of ships, ports, safety at sea, employment and training, and administration. ${ }^{52}$ One of the strategic objectives of the policy is "to promote and main- 
tain cooperative international relations with other countries and international organisations involved in maritime affairs". ${ }^{53}$

Alongside this developing foreign policy and the NDP, the government, modelling the Malaysian government's Big Fast Results problem-solving methodology (see Big Fast Results Institute, 2015 $)^{54}$ adopted Operation Phakisa, which is a programme aimed at accelerating the execution of the NDP. ${ }^{55}$ Government launched Operation Phakisa in 2014 in Durban. ${ }^{56}$ The Big Fast Results methodology focuses on "bringing key stakeholders from the private and public sectors, academia, as well as civil society organisations together to collaborate in: detailed problem analysis; priority setting; intervention planning and delivery." ${ }^{57}$ The collaboration sessions are called laboratories (labs) ${ }^{58}$ One of these labs is "Operation Phakisa: Oceans Economy" (OP-OE). This lab focuses on "unlocking the economic potential of South Africa's oceans". ${ }^{59}$ The OP-OE encapsulates the following maritime and maritime industry sectors as areas for advancement:

- marine transport and manufacturing;

- tourism;

- offshore oil and gas;

- construction;

- renewable energy;

- fisheries and aquaculture;

- communication;

- desalination and marine protection services; and

- governance. $^{60}$

However, the oceans division of Operation Phakisa cannot operate in a domestic vacuum. Findlay and Bohler-Muller note:

[T] he fact that the majority of the world's oceans (the high seas) are global commons and that many of the global environmental externalities affecting the oceans are trans-boundary means that ocean resource use, management measures and conservation are dependent on international [instruments]. ${ }^{61}$

\section{Key points from relevant continental policy frameworks}

It is clear that to advance the developmental goals of the OP-OE and the burgeoning global maritime foreign policy, with its focus on the African continent, South Africa must be mindful of continental instruments in the maritime space and promote these.

Agenda 2063 is the continent's strategic framework that aims to deliver on its goal for inclusive and sustainable development on the continent. ${ }^{62}$ Under the auspices of the African Union (AU), this framework aims, amongst other things, for a "prosperous Africa based on inclusive growth and sustainable development". ${ }^{63}$ To this end, it acknowledges: 
Africa's Blue/ocean economy, which is three times the size of its landmass, shall be a major contributor to continental transformation and growth, through knowledge on marine and aquatic biotechnology, the growth of an Africa-wide shipping industry, the development of sea, river and lake transport and fishing; and the exploitation and beneficiation of deep sea mineral and other resources. ${ }^{64}$

The AU Assembly decided in July 2010 that "a rational and coordinated policy for maritime and coastal activities with a view to making the best of the Continent's maritime wealth" ${ }^{65}$ was needed, and the AU Commission took on the challenge of elaborating and formulating the Africa Integrated Maritime Strategy (AIMS) 2050, ${ }^{66}$ which was adopted by the AU Assembly in $2014 .{ }^{67}$ The strategy was -

[D]eveloped as a tool to address Africa's maritime challenges for sustainable development and competitiveness. The strategy aims to foster more wealth creation from Africa's oceans, seas and inland water ways by developing a thriving maritime economy and realizing the full potential of sea-based activities in an environmentally sustainable manner. ${ }^{68}$

The overarching vision of the strategy is "to foster increased wealth creation from Africa's oceans and seas by developing a sustainable thriving blue economy in a secure and environmentally sustainable manner". ${ }^{69}$

Moving from soft-law, non-binding policy documents to legally binding instruments, the African Union Extraordinary Summit held in Togo in 2016 resulted in the adoption of the African Charter on Maritime Security and Safety and Development in Africa (the Lomé Charter). ${ }^{70}$ The charter provides a definition of the blue/ocean economy with one of the objectives being the promotion of a flourishing and sustainable blue/ ocean economy. ${ }^{71}$ The charter further contains a chapter on the development of the blue/ ocean economy with provisions on:

- exploitation of the maritime domain, fisheries and aquaculture;

- creation of wealth and jobs through coastal and marine tourism;

- integrated human resource strategy for maritime development;

- competitiveness improvement;

- development of infrastructure and equipment relating to maritime activities (AIMS);

- measures to mitigate climate change and environmental threats;

- protection of marine biological species, fauna and flora;

- toxic and hazardous waste dumping;

- prevention of illegal exploitation and theft of marine resources; and

- maritime disaster risk management. 
The charter also contains a chapter on cooperation with provisions relating to cooperation in:

- exploitation of the maritime domain;

- fishing and aquaculture;

- combatting crimes at sea;

- intelligence sharing, scientific and academic cooperation; and

- maritime information sharing.

\section{Impetus for foreign engagement: Primacy of African interests as the golden thread}

It is patent from the rendition of the policies above that diplomacy and advocacy are critical for the government to be credible and effective in its domestic and foreign policy engagements. ${ }^{72}$ Indeed, Hengari notes, "in fulfilling the African Agenda, South Africa's diplomacy does not begin on a blank page: a number of initiatives have gathered pace after 20 years of engagement and practice". ${ }^{73}$ The increasing emphasis by the government on the blue economy, together with the continental initiatives places South Africa in a strong position to develop synergies between initiatives in the national interest of the country and meaningful continental maritime policy. ${ }^{74}$ This is in agreement with the country's diplomacy of $u$ buntu, namely striving to address domestic imperatives while taking into cognisance the needs and aspirations of others. ${ }^{75}$

What also emerges prominently is the primacy of Africa in South Africa's international affairs. This focus is the golden thread that weaves though South Africa's engagements in the international area. Minister Nkoana-Mashabane remarked, "[t]he African continent remains central in our foreign policy, and this approach forms the basis of our friendship, cooperation and peace efforts all over the world." ${ }^{\prime 76}$

South Africa is in a position to harness its relative power on the continent to drive reform and development in the international area for the benefit of the continent. However, with a foreign policy that is expansive, nuanced and multi-faceted, the manner in which resources are deployed and the extent of political will demonstrated to determine whether the golden thread in South Africa's global foreign maritime policy of deepening engagement with Africa is met, should be analysed.

\section{Accessions to international instruments and international memberships}

South Africa's diplomacy and engagement with international maritime affairs occurs through participation in global instruments and organisations. South Africa is a signatory to various international instruments in the maritime space, from framework conventions, such as UNCLOS, ${ }^{77}$ to various instruments adopted under the International Maritime Organisation (IMO) ${ }^{78}$ for example:

- the International Convention Relating to Intervention on the High Seas in Cases of Oil Pollution Casualties, $1969 ;{ }^{79}$ 
- the Convention on the International Regulations for Preventing Collisions at Sea, $1972 ; 80$

- the International Convention for the Safety of Life at Sea, $1974 ;{ }^{81}$

- the International Convention on Standards of Training, Certification and Watchkeeping for Seafarers, 1978; ${ }^{82}$

- the Convention for the Suppression of Unlawful Acts against the Safety of Maritime Navigation, 1988; ${ }^{83}$

- the International Convention for the Control and Management of Ship's Ballast Water and Sediments, 2004; ${ }^{84}$ and

- the Nairobi International Convention on the Removal of Wrecks, $2007 .{ }^{85}$

A fuller description of accessions of international instruments by South Africa has been given elsewhere. ${ }^{86}$ Participation in these instruments often result in the adoption of domestic enabling legislation ${ }^{87}$ and implementation of the obligations of these instruments entrusted to specific governmental departments or agencies, such as the South African Maritime Safety Authority (SAMSA). These obligations are not always fulfilled. A recent example of how such obligations are not always fulfilled is illustrated in a circular issued by the IMO ${ }^{88}$ The circular expressed its intention to remove from its register all countries that were not compliant with the International Convention on Standards of Training, Certification and Watchkeeping for Seafarers, 1978. South Africa was on the list earmarked for removal due to non-compliance. ${ }^{89}$ In a media statement, SAMSA acting chief executive officer (CEO), Sobantu Tilayi said, "the agency was extremely concerned by the development, as it had major implications for the country's maritime sector" ${ }^{90}$ However, a more probative way to chart the direction of South Africa's global maritime foreign policy is to describe the country's contributions to and memberships of global and regional organisations. These memberships and contributions will be categorised and considered below in the following spheres and geographical regions.

\section{International memberships in the marine sphere}

The International Whaling Commission (IWC) was established in 1946 under the International Convention for the Regulation of Whaling, which came into force in 1948 (see International Whaling Commission, 2020). ${ }^{91}$ The IWC has as its main objective the conservation of whale stocks and the orderly development of the whaling industry in terms of the regulations of the Convention. South Africa is presently a member of the IWC contributions review committee. ${ }^{92}$ The Department of International Relations and Cooperation (DIRCO) reports, "South Africa is a founder nation and has an excellent record for contributing towards its conservation objective and research aimed at providing a scientific basis for whale stock management." ${ }^{93}$ In 2016, South Africa hosted two IWC workshops on cetacean welfare. ${ }^{94}$

The International Commission for the Conservation of Atlantic Tunas (ICCAT) was established in 1969. The objective of ICCAT is to maintain the population of tuna and tuna-like fish in the Atlantic Ocean at levels that will permit maximum sustainable yields, as well as the implementation of research programmes, the analysis of fishing 
statistics and the formulation of stock conservation recommendations. ${ }^{95}$ DIRCO reports, "South Africa is a founding member of ICCAT, and has maintained full membership since then. South Africa's commercial and recreational fishery for tuna and swordfish depend on highly migratory stocks, which are fished in international waters. ${ }^{966}$ DIRCO noted with concern that:

As a developing southern Atlantic coastal state participating in the tuna fishery, South Africa must exercise its right to these resources and defend this right against northern hemisphere highly industrialised countries and distant water fleets, currently involved in over fishing in the South Atlantic Ocean. ${ }^{97}$

South African scientific research into tuna management is ongoing. It was reported, "no less than 20 papers and presentations were prepared and delivered by South African fisheries scientists [last] year". ${ }^{98}$ ICCAT reported:

South African National Department of Agriculture, Forestry and Fisheries (DAFF) is working independently and in collaboration with scientists from other CPCs [Contracting Parties and Cooperating Contracting Parties, Entities or Fishing Entities] and NGOs [non-governmental organisations] to carry out research related to large pelagic fisheries ... [and] [c]ollaborative research projects investigating the stock origin and intermixing of tuna and swordfish and shark populations at the boundary between the Atlantic and Indian Oceans are ongoing and remain a high research priority in South Africa. ${ }^{99}$

\section{International memberships in the nautical sphere}

The International Hydrographic Organisation (IHO) was founded in 1921 with the main objective of promoting uniformity in nautical charts and documents to coordinate the activities of national hydrographic offices, and the adoption of reliable and efficient methods in carrying out and exploiting hydrographic surveys. ${ }^{100}$ South Africa became a member of the IHO in 1951 and ratified the IHO Convention in 1968. ${ }^{101}$ The country has since played an active role by assisting Mozambique in printing hydrographic charts and training members of the navies of neighbouring countries at South Africa's Hydrographic School. ${ }^{102}$ Membership of the IHO has enhanced maritime safety within the Southern African region. South Africa chairs the Southern Africa and Islands Hydrographic Commission (SAIHC). One of the objectives of the SAIHC is to build capacity in the region. ${ }^{103}$ Significant progress was made in this regard in November 2018 with the steel-cutting ceremony of a newly commissioned hydrographic survey vessel (HSV) for the South African Navy to support the various governmental imperatives. ${ }^{104}$ The construction of this vessel was labelled as an African first, and it is being built by a company, which is 67 per cent black women-owned. The vessel is due for delivery in 2022 and will replace the SAS Protea which has been in service since 1972. ${ }^{105}$ President Zuma noted that this was an investment of R1,8 billion. ${ }^{106}$ Regarding capacity, a Department of Defence Briefing noted that South Africa was one of the few countries on the 
African continent that was able to produce a full set of charts. ${ }^{107}$ South Africa provided assistance, such as printing charts and training hydrographers, to neighbouring countries that lacked capacity to undertake its hydrographic responsibilities. ${ }^{108}$

The Brief also noted:

The United Nations evaluated countries in terms of their capacity and capability and the South African Hydrographic Office had been placed in the class one category. There were only 13 countries in the world which met the standards of the class one classification. ${ }^{109}$

The Intergovernmental Oceanographic Commission (IOC) was established within UNESCO in 1960. The IOC has a coordinating, stimulatory and integrating role in marine science and technology and functions by means of various subsidiaries. ${ }^{110}$ The DIRCO reports, "South Africa has been an active member of the IOC and has since 1995 enjoyed a position on the IOC Executive Council." "111 The South African oceanographic research vessel, SA Agulhas II undertook its first cruise in the framework of the second International Indian Ocean Expedition (IIOE2) from Durban on 17 October 2017 to Dar es Salaam and returning to Durban on 13 November 2017. ${ }^{12}$ Minister Molewa commented:

The SA vessel the SA Agulhas II left Cape Town late last month. On board were over 200 research scientists from the continent and internationally, including students to collect data on the Indian Ocean. Their respective specialities include physics, chemistry, plankton, biodiversity, biology, whales, seals \& seabirds and geology. The data they collect will provide much-needed information that will aid in our understanding of the ocean environment and its links to its sustainable development ... Capacity development and information on ocean dynamics knows no boundaries. What happens in the Indian Ocean is also of our concern. ${ }^{113}$

\section{International memberships related to the Southern Ocean}

The Antarctic Treaty System (ATS) provides the framework for international co-operation under which various conventions and protocols regarding Antarctica were negotiated. ${ }^{114}$ South Africa ratified the Antarctic Treaty ${ }^{115}$ in June 1960 and is the only African state that is party to the Treaty. ${ }^{116}$ The DIRCO reports:

[T] he port of Cape Town has increasingly become a gateway for research vessels on their way to Antarctica, and the potential is there for future growth in co-ordinating this activity. The Antarctic Treaty is a model of international co-existence and co-operation. The conservation of the Antarctic environment and its ecosystem is of cardinal importance to South Africa, whose own environment is directly influenced by the Antarctic continent. ${ }^{117}$ 
The South African Antarctic and Southern Ocean Research Plan 2014-2024 (see Skelton, 2014), prepared for the South African National Research Foundation, notes:

South Africa, a founding member of the [ATS], has a long-term track record of, and commitment to undertaking oceanic, terrestrial and atmospheric research in Antarctica and the Southern Ocean. This includes work at its sub-Antarctic Prince Edward Islands, in collaboration with the United Kingdom at Gough Island, where it has a weather station, and at the Tristan islands. ${ }^{118}$

The Plan also states:

South Africa has a comparative geographic advantage for conducting research in Antarctica and the Southern Ocean. It is the closest African nation to the Austral Polar region, separated from the continent of Antarctica by approximately $4000 \mathrm{~km}$ of Open Ocean that contains a regionally unique configuration of ocean circulation, making the region key to understanding past, present and future evolution of global climate. $^{119}$

Accordingly, the Plan shows that "South Africa therefore bears a regional responsibility and serves as a springboard for broader African scientific research interests in the Antarctic region." 120

International memberships related to the Indian Ocean

The genesis of the Indian Ocean Rim Association (IORA) can be traced back to 1995, when, during a visit to India, President Mandela remarked:

[T] he natural urge of the facts of history and geography ... should broaden itself to include the concept of an Indian Ocean Rim for socio-economic co-operation and other peaceful endeavours ... [r]ecent changes in the international system demand that the countries of the Indian Ocean shall become a single platform. ${ }^{121}$

The Indian Ocean rim is one of the most diverse and geo-strategically important regions of the world "with a heterogeneous mix of developed, developing, least developed countries and small island developing States". ${ }^{122}$ South Africa was one of the founding members of IORA and was a signatory to its Charter in 1997. ${ }^{123}$ Minister Sisulu remarked, "[t]he geostrategic importance and profile of the Indian Ocean Region is growing rapidly, with an unprecedented focus and attention on the potential contribution that the Region can and should be making towards global security, economic growth, and sustainable development." ${ }^{124}$ South Africa assumed the chair of IORA in October 2017. The Council of Ministers of IORA appointed South African diplomat Dr Nomvuyo Nokwe as the Secretary-General of IORA. ${ }^{125}$ The theme of South Africa's chairship of IORA is "IORA: uniting the Peoples of Africa, Asia, Australasia and the Middle East through Enhanced Co-operation for Peace, Stability and Sustainable Development". ${ }^{126}$ 
Minister Sisulu further remarked, "this theme encompasses South Africa's view that the Indian Ocean Region should be characterized as a region of peace, stability and development; and we consider IORA as the pre-eminent regional organisation within which to pursue this ambitious goal". ${ }^{127}$

Former Minister Nkoana-Mashabane remarked that three priorities would be pursued during the South African chairship of IORA, namely:

- maritime safety and security in the region, including prioritising the establishment of the Working Group on Maritime Safety and Security;

- improving resilience and responses for disaster risk management, including prioritising the implementation of the Memorandum of Understanding on Search and Rescue; and

- sustainable and responsible fisheries management and development, including dealing with the important issue of illegal, unreported and unregulated fishing. ${ }^{128}$

Deputy Minister Landers stated in 2018 that, through the chairship, South Africa aimed to strengthen institutional mechanisms, bodies and the secretariat of the IORA. ${ }^{129}$ He commented:

[South Africa] is in the process of establishing new dedicated functional bodies to deal specifically with critical priorities in areas such as Maritime Safety and Security, the Blue Economy, Women's Economic Empowerment, and Tourism. There is also a strong focus on enhancing trade and investment between IORA members; empowering the youth; ensuring the effective utilisation of resources, such as water and fisheries; and promoting research, development and innovation, including through the 2nd International Indian Ocean Expedition. ${ }^{130}$

South Africa intended to use the platform to deepen and strengthen ties with international and regional bodies such as the United Nations (UN), the African Union (AU), Association of Southeast Asian Nations (ASEAN) and Asia-Pacific Economic Cooperation (APEC) and being supportive of the initiatives under Agenda 2063 and the Africa's Integrated Maritime Strategy (AIMS or AIM Strategy) . ${ }^{131}$

\section{International memberships related to the Atlantic Ocean}

South Africa has also engaged with its neighbours on its Atlantic seaboard. The governments of Angola, Namibia and South Africa signed the Benguela Current Convention (BCC) in the Angolan city of Benguela in March 2013. ${ }^{132}$ The Convention is a formal treaty between the governments of Angola, Namibia and South Africa. The objective is "to promote a coordinated regional approach to the long-term conservation, protection, rehabilitation, enhancement and sustainable use of the Benguela Current Large Marine Ecosystem, to provide economic, environmental and social benefits". ${ }^{133}$ 
South Africa ratified the BCC in 2014. Minister Molewa, speaking at the $6^{\text {th }}$ Ministerial Conference of the BCC highlighted South Africa's commitment to:

[S]trengthening collaboration in the management of transboundary resources, skills capacity and training of our professionals as well as research scientists on key areas falling within the scope of the work of the BCC. We committed to work together in the following fields: (i) combating illegal, unregulated and unreported fishing (IUU fishing) within the existing frameworks; (ii) ensuring maximum sustainable utilization of the resources for the benefit of the region; (iii) bringing in, empowering and encouraging participation of youth and women in the [Benguela Current Large Marine Ecosystem]; (iv) collaborating in the handling of oil spill emergencies; (v) addressing new developmental demands; and (v) the Oceans Economy. ${ }^{134}$

South Africa's reach on her western seaboard ventured further, and since the beginning of 2015, it deployed frigates, submarines and over 220 members of the South African Defence Force (SADF) to combat piracy activities targeting oil tankers in the Gulf of Guinea. ${ }^{135}$ On a broader multilateral arena, South Africa is a party, along with 23 other countries to the Zone of Peace and Cooperation of the South Atlantic (ZPCSA), established in $1986 .{ }^{136}$ In a reply to a report of the Secretary-General of the UN in 1995 , South Africa noted -

[The country] reaffirms its belief in the zone as a veritable instrument for promoting international peace and security as well as development cooperation [and] [a]s a mark of its commitment, South Africa will be hosting the fourth ministerial meeting of the zone in Cape Town, South Africa, early in $1996 .{ }^{137}$

Development in the region was hindered as South Africa was the only African nation with long-range naval capabilities. ${ }^{138}$

Lalbahadur et al. comment how in ZPCSA, the oceans economy have opened new avenues of cooperation between South Africa and Brazil: with new discoveries of light oil and gas deposits off the coast of Brazil and an estimated nine billion barrels of oil and ten billion barrels of natural gas laying untapped in South Africa's exclusive economic zone. ${ }^{139}$ The authors further comment that these discoveries created the impetus for both countries to improve their maritime security and co-operation. ${ }^{140}$ South Africa has accordingly participated in military exercises under the rubric of the India-Brazil-South Africa maritime cooperation (IBSAMAR) and under the rubric of Brazil, Argentina and Uruguay (ATLASUR). ${ }^{141}$ 


\section{Membership of the International Maritime Organisation}

Whilst South Africa is a party to the numerous conventions adopted under the auspices of the International Maritime Organisation (IMO), the country has had a long association of involvement in the organisation itself. South Africa was admitted as a full member in 1995 and had served as vice-chair of the IMO Council from 2005 to 2015. In 2017, a statement from the cabinet confirmed that South Africa was to bid for a re-election to the IMO Council (the executive organ of the IMO responsible for supervising the work of the organisation), competing against 25 other countries, with the rationale that such membership would contribute to employment growth derived from OP-OE. ${ }^{142}$ Deputy Minister Chikunga briefed the media that the re-election would "ensure that the Southern African Development Community is represented in global maritime affairs and continues to advance its maritime agenda and a vision of becoming an International Maritime Centre (IMC) and strategic partner in world maritime affairs". ${ }^{143}$ The government despatched a high-level contingent to the IMO session in London in November 2017, comprising the Deputy Minister of Transport, supported by officials from the Departments of Transport and DIRCO, SAMSA and Transnet. ${ }^{144}$ In a statement delivered at the IMO, Deputy Minister Chikunga stated:

South Africa will continue to play her meaningful role in addressing some of the maritime related challenges facing the global community. We will continue to put together our collaborative efforts and work with all relevant stakeholders in contributing towards the sustainable green economy. ${ }^{145}$

The Deputy Minister used the opportunity to canvass support linked to South Africa's African-centred foreign policy by stating:

South Africa is the only country in the Southern African Development Community (SADC) Region of Africa standing for being re-elected in the IMO Council. Against this background, South Africa appeals to IMO Member States in Africa, Europe, the Americas, Asia and Oceanic states for support in her quest to retain her position in Council. The re-election of South Africa to the Council will ensure that the developing countries in general and the African continent in particular gets a fair voice in the international maritime affairs. ${ }^{146}$

In this statement, the deputy minister drew the attention of the IMO to the fact that South Africa is actively operationalising the provisions of AIMS, and through partnership with the IMO, has converted her Maritime Rescue Co-ordination Centre to a Regional Maritime Rescue Co-ordination Centre. ${ }^{147}$ Lastly, it was reported that, in an effort to grow existing relations with the IMO, South Africa would host the World Maritime Day Parallel Event which will be held from 28-30 October 2020 in Durban. The event will seek to highlight the significant role of global shipping and the role of the IMO. ${ }^{148}$ South Africa was successful in its bid and was re-elected to the Council on 1 December 2017. ${ }^{149}$ 


\section{Capacity and resources}

The above ministerial statements must however still translate into implementation. The NDP acknowledges, "South African diplomats have great skill in drafting memoranda of understanding, policy statements and agreements, but lose momentum when it comes to implementing agreement terms or following up on promises of benefits."150 Minister Nzimande commented in 2019, "we have gone beyond conceptual frameworks, we can no longer be in a state of unending planning, and we need to accelerate implementation". ${ }^{151}$ There are instances of investments in innovation and infrastructure that lend credence to the government's desire to implement their domestic and foreign policies effectively. For example, the Department of Science and Technology (DST) stated in 2019 that it would invest R27 million in the country's Maritime Domain Awareness satellite programme. ${ }^{152}$ The DST launched the ZACube-2 nanosatellite, considered the most advanced on the continent, which carries an automatic identification system (AIS) for monitoring the movement of ships along the South African coastline. ${ }^{153}$ These initiatives will support data-exchange systems for the maritime industry and ship operations to support OP-OE. ${ }^{154}$ The commissioning of the hydrographic survey vessel can also be seen as a significant investment to further the country's maritime policies.

President Zuma remarked in 2017 that the government had unlocked investments totalling R24,6 billion with a government contribution of R15 billion. The President further reported that 6500 jobs had been created through OP-OE initiatives. ${ }^{155}$ The country invested in IORA initiatives. It was reported, for example, that US\$150 000 (equivalent to R 2054325 on 10 October 2017) was contributed to fund the IORA action plan for 2017-2021 and for the establishment of the new working groups on the blue economy, maritime safety and security, women's economic empowerment and the core group on tourism. ${ }^{156}$ A further US\$50 000 (equivalent to R 684775 on 10 October 2017) was allocated to the IORA special fund for pilot projects aimed at improving the lives of the IORA region's poorest people, and US\$50 000 (equivalent to R 684775 on 10 October 2017) was allocated to projects in Africa in support of the African oceans economy projects under the AIMS. ${ }^{157}$

\section{Evaluation and perceptions: How influential is South Africa's global maritime policy?}

In the absence of an explicit global maritime foreign policy document, other relevant policy documents discussed above point toward an African-centred approach to global maritime foreign policy, with the continent being inextricably linked to the future of South Africa. The various ministerial statements cited in this article appear to support this approach. Policy is also shaped by and implemented through global or regional agreements and memberships in organisations. However, these agreements and organisations are collectively varied in both their geographical application and the level of contribution or responsibility required of member states. This article has provided a description and categorisation of the wide reach of South Africa's contributions and membership. An argument could be made that the African-centred approach also underscores South Africa's contributions to global and regional organisations, as described, 
for example, in its membership of the IHO and ATS. This approach would consolidate the focus of South Africa's global maritime foreign policy and provide a base to harmonise and align the varying contributions in global and regional fora. In addition to describing the engagement and participation in these fora, the ministerial statements reveal that considerable funding and resources have been allocated to the various programmes and initiatives. This presents a prima facie demonstration of political will to implement policies effectively and comply with international obligations.

Haas, in commenting on features of good maritime governance, notes "a high-level profile for negotiations also encourages breakthroughs and meaningful commitments that mid-level bureaucrats lack the authority to make". ${ }^{158}$ In this instance, OP-OE was conceived and articulated through the Presidency of the Republic and with ministers in the national cabinet contributing to discussions in IORA and the IMO amongst others. The foreign maritime policy approach blends with South Africa's national interest, as set out in the policy documents above. Minister Nkoana-Mashabane noted, "[a] country's foreign policy is firmly premised on its domestic priorities, hence, as South Africa, we expect great dividends from linking IORA's blue economy to our domestic [OPOE]." 159 Benkenstein similarly comments, "the priority areas identified by the South African government for its period as chair of IORA play to the country's strengths and provide opportunities to leverage existing capacity and expertise". ${ }^{160}$

However, global maritime affairs are not always neatly packaged under the auspices of IORA or through OP-OE in domestic maritime affairs. Maritime affairs are fragmented across multiple disciplines and are not easily intertwined. A recent example shows the unlikely interface between private international law and foreign policy. In 2017, the motor vessel (MV) Cherry Blossom entered the port of Coega on the outskirts of Port Elizabeth to take on bunkers en route to Tauranga in New Zealand. The ship was laden with a cargo of phosphate that had been mined in the Boucraa mine in the northern part of Western Sahara. An application was brought in the High Court of South Africa ${ }^{161}$ at Port Elizabeth by the Sahrawi Arab Democratic Republic and the Polisario Front (a national liberation movement). The respondents who were the exporters of the phosphate and shipping the cargo on the Cherry Blossom were two companies registered in accordance with the laws of Morocco. The dispute between the parties concerned the ownership of the cargo aboard the ship. The applicants contended that the cargo aboard the ship was part of the national resources of Western Sahara and belonged to its people, and that the respondents misappropriated the cargo and sold it, having no right to do so. The respondents contended that their right to mine and sell the phosphate was derived from Moroccan law. The applicants intended to institute a vindicatory action in respect of the cargo, and the proceedings in the High Court intended to obtain an interdict and ensure that the cargo remained within the jurisdiction of the court until the vindicatory action had been finalised. ${ }^{162}$ A full bench of the High Court found in favour of the applicants. Following the judgment, it was reported in the media, "Morocco was, obviously, furious about the seizure of the ship. Its state media reporting that SA was trying to 'sabotage' Morocco's commercial interests following its re-admittance to the African Union in [2017]." 163 It was further reported, "[t] he saga was an unprecedented face-off between SA and another African state and the antagonism between the two nations continues to 
brew." 164 This incident demonstrates that policymakers should be acutely aware of how activities in global shipping and admiralty proceedings could affect foreign relations.

\section{IORA as a platform to consolidate South Africa's global maritime foreign policy}

Nevertheless, despite the fragmented and multi-faceted nature of maritime affairs in order to form an assessment of how meaningful South African contributions are in international organisations and whether the country is capable of exercising power and influence in the formulation of global maritime policy, a scrutiny of a leadership role held by South Africa would provide a firm foundation. The leadership role held by South Africa over IORA through its multiple streams of activities provides South Africa with a concrete platform to develop a clear articulation of the nature and extent of its international maritime policy. Earlier in this article, an overview was provided of South Africa's goals for its chairship of IORA. Have these goals been met? South Africa's chairship ended in October 2019 and a meeting of senior officials was convened by South Africa in Durban on 19 June 2019. This provided an opportunity to reflect on South Africa's chairship. A press release reporting on the outcomes of the meeting presented a positive picture. The South African chair of the committee of senior officials, Ambassador Sooklal, commented:

[B]y working together we have achieved significant milestones ... [that] will put [IORA] in a position to become one of the major regional bodies that can contribute, as a grouping to the greater global good, in addition to re-enforcing its position as the Apex Organisation for the Indian Ocean. ${ }^{165}$

The ambassador also acknowledged the significant achievements made during South Africa's chairship, including the advancement of IORA's Action Plan (2017-2021). ${ }^{166}$ These statements point toward South Africa's capacity to lead global discourse. A handing-over report detailing South Africa's progress as chair was presented by Minister Pandor to the incumbent chair of IORA at the $19^{\text {th }}$ IORA Council of Ministers on 7 November 2019. ${ }^{167}$ To date, the report is not accessible in the public domain and this precludes an objective and rigorous analysis of South Africa's contributions to IORA at this stage.

The platform provided by IORA, however, led to discourse held at the highest levels of government. For example, on 20 March 2017, a summit was convened in Jakarta to mark the twentieth anniversary of IORA. The summit brought together leaders of 21 IORA member states and seven dialogue partners with other special invitees. ${ }^{168}$ The summit was seen as a game-changer for regional cooperation and a demonstration of the commitment by member states and dialogue partners to the Indian Ocean region. ${ }^{169}$ At the summit, member states issued the Jakarta Concord: Promoting Regional Cooperation for a Peaceful, Stable and Prosperous Indian Ocean. ${ }^{170}$ A significant provision into the Concord at preambular paragraph 4 was the inclusion of United Nations General Assembly Resolution 2382 (XXVI) of 16 December 1971 on the Declaration of the Indian Ocean as a Zone of Peace. ${ }^{171}$ The IORA member states recalled the resolution and affirmed the commitment to maintain peace and stability in the Indian Ocean region. It 
is particularly noteworthy that the recollection, affirmation and inclusion of the Zone of Peace into the Concord was tabled and advocated by South Africa. ${ }^{172}$ Anand notes that this contribution was one of the most significant achievements of South Africa's participation in IORA. ${ }^{173}$ This demonstrated South Africa's capacity to influence global discourse. Although recalling the resolution was seen as significant, it was adopted during the Cold War era, when issues pertaining to major power conflict and arms control were at the forefront. For South Africa to continue advocating the successful execution of this provision of the Concord, it is apt to note Du Plessis's remarks in 1987 regarding the original declaration, namely

[A] basic problem with this type of declaration is the fact that its operationalization is dependent on the degree to which it is reconcilable with major power interests. Due to its non-enforceable nature, and the degree to which it reflects particular international persuasions, it can, at best, place moral restrictions on the actions of major powers. ${ }^{174}$

A similar opportunity to influence global policy will arise through membership of the IMO Council. Such leadership would not only benefit the country, but also the organisation itself. Benkenstein notes that IORA had an underwhelming past, and "states expected to have played a strong leadership role ... did not prioritise the wider Indian Ocean region in their foreign policies in the decade following [IORA's] establishment". ${ }^{175}$ The ministerial statements cited above move away from this apathy, and Benkenstein also notes that under OP-OE, South Africa has been "positioning itself as a strong maritime nation seeking to take advantage of its strategic position bordering three major oceans". ${ }^{176}$ The diplomacy engaged by a country, according to Lalbahadur and Du Plessis, is vital to ensure its interests are defended and advanced in international rule marking, and that its own position and international prestige are enhanced. ${ }^{177}$

A strong case could be made for the appellation of South Africa, as the most developed economy on the continent, as primus inter pares on the continent. Minister Nzo remarked during the nascent days of South Africa's first democratic government:

[T] he position in which South Africa finds itself is that it has features both of the developed and the developing world. It is truly at the point of intersection between both worlds - an industrialised state of the South which can communicate with the North on equal terms to articulate the needs, the concerns and the fears of the developing world. Conversely we can interpret the concerns and the fears of the developed world. ${ }^{178}$

This fits in with the criteria of an emerging middle power, i.e. "a state with enough gravitas and international support to act as a regional and international broker, mediator and bridge-builder in the interest of international peace and stability". ${ }^{179}$ South Africa's soft power was apparent through the support and admiration for South Africa's peaceful democratisation and narrative of reconciliation. However, the foreign policy discussion document expressly acknowledges: 
[T] he world's reaction does not represent an indefinite continuation of the unique relationship or so-called honeymoon which South Africa has experienced since 1994. Many expectations about South Africa's international role have been created, but at the same time many demanding responsibilities have been assumed. ${ }^{180}$

South Africa is expected to play a complex role, at many levels, for example, in the SADC region where states expect that South Africa interacts with them as a partner and ally rather than at a regional level, and there are expectations of South Africa at continental level to contribute to peace and development. ${ }^{181}$ The NDP, however, acknowledges that South Africa has lost a great deal of moral authority as a power resource. ${ }^{182}$ Although South Africa aims to lead with an African centrist perspective, researchers for the South African Institute of International Affairs - who conducted a study by interviewing AU officials for their views on South African policy - however provided a sobering view. They found that there is a marked difference between how South Africans - as people and as a government - see themselves and how the rest of the continent perceives them. ${ }^{183}$ The perception is that South Africa does not use these leadership platforms to create or promote opportunities for wider African involvement, but rather in order for its own economic interests to enjoy priority always. ${ }^{184}$ Secondly, they perceived South Africa's conduct in the AU as that of a 'bully' or 'big brother'. ${ }^{185}$ Whilst the documents and ministerial speeches cited above could factually dissuade these notions, Kelafe et al. ultimately argue, "in the diplomatic world, perceptions matter as much as the facts in the formulation of policy responses". ${ }^{186}$ In light of the above considerations, the synergy of South Africa's global maritime foreign policy trends with its ongoing involvement in global and regional fora will be keenly observed. 


\section{ENDNOTES}

${ }^{1}$ LLB, LLM (Maritime Law), PhD (UKZN), Admitted Attorney and Notary Public of the High Court of South Africa, senior lecturer: School of Law, University of KwaZulu-Natal, Durban. Email: surbun@ukzn.ac.za.

${ }^{2}$ A du Plessis. South Africa and the South Atlantic Ocean: A maritime-strategic analy sis. Pretoria: Institute for Strategic Studies, University of Pretoria, 1987, 60.

${ }^{3}$ Associated Press Archive. "Vorster speaking at National Party rally at Pietermaritz burg". Film footage. Syndicate 241177, 1977. Du Plessis, however, commented that the then Soviet Union had multiple global and regional interests, of which South Africa constituted a less significant part. He noted particularly that "Soviet involvement in the area should not be seen as a part of a coordinated geopolitical masterplan with South Africa's maritime value being the only goal". Du Plessis op. cit., p. 83.

${ }^{4}$ Du Plessis op. cit., p. 57.

${ }^{5}$ Ibid., p. 58.

${ }^{6}$ Ibid., p. 84.

${ }^{7}$ RJ Hanks. The Cape Sea Route: Imperiled Western lifeline. Washington, DC: Institute for Foreign Policy Analysis, 1981, 55.

${ }^{8}$ DJ Devine. "South Africa and the law of the sea: Problems common, uncommon and unique". Acta Juridica 29. 1986. 36; see also R Suttner. "Has South African been illegally excluded from the United Nations General Assembly?" Comparative and International Law Journal of Southern Africa 17. 1984. 279-301.

${ }^{9}$ Devine op. cit., p. 36.

${ }^{10} \mathrm{P}$ Vrancken. "International law of the sea in South Africa". In De Wet, E \& Hester meyer, H (eds), The reception of international law in South Africa: Strengthening the rule of law by following the German model? Pretoria: Pretoria University Press, 2015, 144.

${ }^{11}$ Devine op. cit., p. 35.

${ }^{12}$ Ibid., p. 37.

${ }^{13}$ The Final Act of the Third United Nations Conference on the Law of the Sea, Annex I, Resolution IV and Appendix "Liberation Movements"; see International legal materials 21. 1982. 1258, 1259; see further Devine op. cit. p. 36; see further Article 305 of UNCLOS.

${ }^{14}$ South African Government. "Minister Maite Nkoana-Mashabane: Opening remarks at the Indian Ocean Rim Association $17^{\text {th }}$ Meeting of the Council of Ministers". 18 October 2017. <https://www.gov.za/speeches/minister-maite-nkoana-mashabane-opening-remarks-indian-ocean-rim-association-17th-meeting $>$ Accessed on 24 April 2019. 
${ }^{15}$ South African Government. "Minister Edna Molewa: 6th Ministerial Conference of Benguela Current Convention”. 9 November 2017.

$<$ https://www.gov.za/speeches/minister-edna-molewa-6th-ministerial-conference-benguela-current-convention-9-nov-2017-0000 $>$ Accessed on 24 April 2019.

${ }^{16}$ Wilton Park. “Report: Implementing Africa’s maritime security strategies”. 2015. <https:/www.wiltonpark.org.uk/wp-content/uploads/WP1407-Report.pdf> Accessed on 25 April 2019.

${ }^{17}$ DIRCO (Department of International Relations and Cooperation). "Opening remarks and country statement by Minister GNM Pandor at the $19^{\text {th }}$ Meeting of the IORA Council of Ministers (COM), Abu Dhabi, United Arab Emirates, Thursday, 7 November 2019". $\quad<$ http://www.dirco.gov.za/docs/speeches/2019/ pand1107.htm $>$ Accessed on 1 February 2020.

18 P Fougstedt, CJ Furness \& RH Harm. "The needs for a national maritime policy". Scientia Militaria 19/2. 1989. 44.

${ }^{19}$ Ibid., p. 41

${ }^{20}$ ZD Singh. "Foreign policy and sea power: India's maritime role flux". Journal of Defence Studies 11/4. 2017. 22.

${ }^{21}$ Fougstedt et al. op. cit., p. 40.

22 South African Government. "Foreign Policy for South Africa: Discussion docu ment". 1 June 1996. <https://www.gov.za/documents/foreign-policy-south-africa-discussion-document $>$ Accessed on 25 April 2019, par 5.2.

${ }^{23}$ NPC (National Planning Commission). "National Development Plan 2030”. 2020.

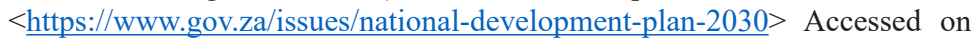
24 April 2019.

${ }^{24}$ Ibid., p. 95.

25 Ibid., p. 236.

26 Ibid., p. 243.

27 Ibid., p. 236.

${ }^{28}$ Ibid., p. 240.

${ }^{29}$ Ibid., p. 85.

${ }^{30}$ Ibid., p. 85.

31 Ibid., p. 238.

${ }^{32}$ Ibid., p. 248.

33 Ibid., p. 249.

34 Ibid., p. 255.

${ }^{35}$ South African Government, "Foreign Policy for South Africa ..." op. cit.

${ }^{36}$ Ibid., par 5.2. 
37 Ibid., par 4.2 .

38 Ibid., par 6.2 .

${ }^{39}$ Ibid., par 6.1.

${ }^{40}$ Ibid., par 5.3.

41 Ibid.

${ }^{42}$ Ibid., par 3.3 .

43 South African Government. "White Paper on South African Foreign Policy". 2011. $<$ https://www.gov.za/documents/white-paper-south-african-foreign-policy-building-better-world-diplomacy-ubuntu> Accessed on 25 April 2019.

44 T Wheeler. "South Africa's foreign policy objectives: Reviewing the White Paper". South African Institute of International Affairs. 31 August 2011. <https:// saiia.org.za/research/south-africas-foreign-policy-objectives-reviewing-the-white-paper/> Accessed on 22 April 2019.

${ }^{45}$ South African Government, "White Paper on South African Foreign Policy" op. cit., p. 3.

${ }^{46}$ Ibid., p. 27.

47 Ibid.

${ }^{48}$ Ibid., p. 11.

${ }^{49}$ Ibid., p. 1.

${ }^{50}$ Ibid., p. 21.

${ }^{51}$ South African Government. "Draft Revised White Paper on National Transport Policy”.2017.<https://www.gov.za/documents/national-transport-policywhite-paper $>$ Accessed on 24 April 2019.

52 Ibid., par 2.2 .

${ }^{53}$ Ibid., par 2.2.2.

${ }^{54}$ See Big Fast Results Institute. 2015. < bfrinstitute.com> Accessed on 1 March 2020.

${ }^{55}$ See in general Department of Environmental Affairs. "Operation Phakisa: Oceans economy". 2019. <https://www.environment.gov.za/projectsprogrammes/operationphakisa/oceanseconomy $>$ Accessed on 24 April 2019.

56 Ibid.

57 Ibid.

58 Ibid.

${ }^{59}$ Ibid.

${ }^{60}$ K Findlay \& N Bohler-Muller. "South Africa's ocean economy and Operation Phakisa”. In Attri, VN \& Bohler-Muller, N (eds), The blue economy handbook of the Indian Ocean Region. Pretoria: Africa Institute of South Africa Press, 2018. 237. 
61 Ibid., p. 233.

${ }^{62}$ See African Union. "Agenda 2063: The Africa we want”. 2015. $<\underline{\text { https://au.int/en/ }}$ agenda2063/overview $>$ Accessed on 1 May 2019. [Make sure of the date. In the next footnote, you gave the full details, with 2015 as date, but I don't see it on the webpage: Date is correct]

${ }^{63}$ Ibid., par 8 .

${ }^{64}$ Ibid., par 5.

${ }^{65}$ African Union Assembly. "Decision on the adoption and implementation of the 2050 Africa's Integrated Maritime Strategy (2050 AIM Strategy)”. AU Doc. Assembly/AU/Dec. 496 (XXII). January 2014.

${ }^{66}$ Full text available at: African Union. "2050 Africa’s Integrated Maritime Strategy

(2050 AIM Strategy)”. 2012. < $\underline{\text { https://cggrps.com/wp-content/up- }}$ loads/2050-AIM-Strategy_EN.pdf $>$ Accessed on 24 April 2019.

${ }^{67}$ African Union Assembly. "Decision on the adoption and implementation of the 2050 Africa's Integrated Maritime Strategy (2050 AIM Strategy)". AU Doc. Assembly/AU/Dec. 496 (XXII). January 2014.

${ }^{68}$ African Union, "2050 AIM Strategy” op. cit., par 11.

${ }^{69}$ Ibid., par 18.

${ }^{70}$ African Union. "African Charter on Maritime Security and Safety and Development in Africa (Lomé Charter)". 2016. < https://au.int/en/treaties/african-charter-maritime-security-and-safety-and-development-africa-lome-charter $>$ Accessed on 24 April 2019]. The Charter is not yet in force.

${ }^{71}$ African Union, "Lomé Charter" op. cit., art. 3(c).

${ }^{72}$ Molewa op. cit.

${ }^{73}$ T Hengari. South Africa's diplomacy 20 years on: Implementing the African agenda around core values, principles and issues. Policy briefing no. 107. Johannesburg: South African Institute of International Affairs, October 2014, 2.

${ }^{74}$ See A Benkenstein. South Africa's Indian Ocean Rim Association legacy: A more inclusive and open IORA. Policy briefing no. 175. Johannesburg: South African Institute of International Affairs, June 2018, 4.

${ }^{75}$ M Mokoena (ed). "International relations”. South Africa Yearbook. Pretoria: Department of Government Communications and Information Systems, 2017/18, 3.

${ }^{76}$ A Lalbahadur \& R du Plessis. "“The Africa we want': Unpacking the primacy of Africa in South Africa's foreign policy". South African Institute of International Affairs. 4 May 2016. < https://saiia.org.za/research/the-africa-we-wantunpacking-the-primacy-of-africa-in-south-africas-foreign-policy/>Accessed on 22 April 2019.

${ }^{77}$ United Nations. "United Nations Convention on the Law of the Sea. 1982". 1833 Treaty Series 2, (1982). Entered into force on 1 November 1994. 
${ }^{78}$ For a full list of ratifications of IMO instruments by South Africa, see IMO (International Maritime Organisation). "Status of Conventions". 10 April 2019. <http://www.imo.org/en/About/Conventions/StatusOfConventions/ Pages/Default.aspx $>$ Accessed on 21 April 2019.

${ }^{79}$ United Nations. "International Convention Relating to Intervention on the High Seas in Cases of Oil Pollution Casualties. 1969". 970 Treaty Series 212 (acceded to in 1986).

${ }^{80}$ United Nations. "Convention on the International Regulations for Preventing Collisions at Sea. 1972”. 1050 Treaty Series 212 (acceded to in 1976).

${ }^{81}$ United Nations. "International Convention for the Safety of Life at Sea. 1974”. 1184 Treaty Series 1 (acceded to in 1980).

${ }^{82}$ United Nations. "International Convention on Standards of Training, Certification and Watchkeeping for Seafarers. 1978”. 1361 Treaty Series 2 (acceded to in 1983).

${ }^{83}$ United Nations. "Convention for the Suppression of Unlawful Acts against the Safety of Maritime Navigation. 1988”. 1678 Treaty Series 222 (acceded to in 2005).

${ }^{84}$ Acceded to in 2008. See IMO. Status of Conventions".2020. $<\underline{\text { http://www. }}$ imo.org/en/About/Conventions/ListOfConventions/Pages/International-Convention-for-the-Control-and-Management-of-Ships'-Ballast-Water-and-Sediments-(BWM).aspx $>$ Accessed on 1 March 2020.

${ }^{85}$ Nairobi International Convention on the Removal of Wrecks. 2007. 46 International Legal Materials 694 (acceded to in 2005).

${ }^{86}$ P Vrancken. "South Africa". In Vrancken, P (ed), The law of the sea: The African Union and its member states. Cape Town: Juta, 2017, 670-680.

${ }^{87}$ See for example the analysis in P Vrancken. "Post-apartheid South Africa and the sea: First decade legislation (1994-2003)". South African Yearbook of International Law 29/1. 2004. 105-124.

${ }^{88}$ International Maritime Organisation. "Communication of information in accordance with the 1978 STCW Convention, as amended" (the 'white list'). IMO Circ. HTW/6/12. 22 February 2019.

${ }^{89}$ FTW Online. "Samsa concerned by IMO's planned delisting of SA". 3 May 2019. $<$ http://www.ftwonline.co.za/article/191219/Samsa-concerned-by-IMO-s-planned-delisting-of-SA/58?fbclid=IwAR04f6M3GH4Qe9cQ-qPw72sH5r5-EUUdmSGRQ481XfaHIzRaHGgoD2KrA48> Accessed on 24 April 2019.

${ }^{90}$ Ibid.

${ }^{91}$ See International Whaling Commission. 2020. <iwc.int/convention> Accessed on 1 March 2020.

92 See DIRCO public information available at: $<$ http://www.dirco.gov.za/foreign/Mul tilateral/inter/index.html $>$ Accessed on 21 April 2019. 
93 Ibid. For a more detailed assessment of South Africa's policy on whaling, see E Couzens. "Large and grey: Whales, elephants and international law and politics". Unpublished PhD thesis. University of KwaZulu-Natal, 2008, 379-387.

94 International Whaling Commission. "South Africa hosts two workshops on cetacean welfare". 2016. $\leq$ https://iwc.int/south-africa-hosts-two-workshops-on-cetacean-welfa $>$ Accessed on 1 February 2020.

95 DIRCO public information op. cit.

${ }^{96}$ Ibid.

${ }^{97}$ Ibid.

${ }^{98}$ Fishing Industry News and Aquaculture. "Tuna management: South Africa a role model". 10 October 2019. < https://www.fishingindustrynewssa.

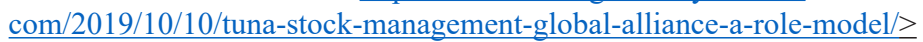
Accessed on 1 February 2020.

${ }^{99}$ International Commission for the Conservation of Atlantic Tunas. "Report for biennial period, 2018-19 Part I(2)". 2019. < $\underline{\text { https://www.iccat.int/Docu- }}$ ments/BienRep/REP_EN_18-19 I-2.pdf $>$ Accessed on 31 January 2020.

100 DIRCO public information op. cit.

${ }^{101}$ M Booi. "Protocol of amendments to International Hydrographic Organisation (IHO) Convention: Department of Defence briefing". Parliamentary Monitoring Group. 8 September 2009. $<\underline{\text { https://pmg.org.za/committee-meet- }}$ ing/10770/> Accessed on 31 January 2020.

102 Ibid.

103 Ibid.

${ }^{104}$ South African Government. "Minister Nosiviwe Mapisa-Nqakula addresses steel cutting ceremony at Southern African Shipyards, 30 Nov". 28 November 2018. < https://www.gov.za/speeches/minister-mapisa-nqakula-delivers-keynote-address-steel-cutting-ceremony-southern-african $>$ Accessed on 22 April 2019.

105 Ocean News. "Kongsberg Technology for South African Navy Survey Vessel”. 1 March 2019. < https://www.oceannews.com/news/science-technology/ kongsberg-technology-for-south-african-navy-survey-vessel > Accessed on 1 March 2019.

${ }^{106}$ South African Government. "President Jacob Zuma: Update on implementation of Operation Phakisa: Oceans Economy Programme”. 6 October 2017. $<$ https://www.gov.za/speeches/president-jacob-zuma-update-implementation-operation-phakisa-oceans-economy-programme-6-oct $>$ Accessed on 22 April 2019.

${ }^{107}$ Booi op. cit.

${ }^{108}$ Ibid. 
${ }^{109}$ Ibid.

${ }^{110}$ DIRCO public information op. cit.

111 Ibid.

112 Second International Indian Ocean Expedition 2015-2020. "Regional Research Cruises in the Western Indian Ocean”. 2017. < https://iioe-2.incois.gov.in/ IIOE-2/EP26-1Info.jsp > Accessed on 1 March 2020.

${ }^{113}$ Molewa op. cit.

114 DIRCO public information op. cit.

115 United Nations. "The Antarctic Treaty". 402 Treaty Series 71. (entered into force on 23 June 1961).

${ }^{116}$ United Nations Office for Disarmament Affairs. “Antarctic Treaty”. 2020. $<$ http://disarmament.un.org/treaties/t/antarctic $>$ Accessed on 31 January 2020.

117 DIRCO public information op. cit.

${ }^{118}$ PH Skelton. "The South African Antarctic and Southern Ocean research plan 2014-2024". National Research Foundation. March 2014. <http://saimi.co. za/downloads/Antarctic\%20and\%20SOuthern $\% 20$ Ocean $\% 20$ Research $\% 20$ Plan.pdf $>$ Accessed on 28 January 2020.

119 Ibid.

${ }^{120}$ Ibid.

${ }^{121}$ DIRCO public information op. cit.

122 South African Government. "Durban Communiqué: The 17th Meeting of the Council of Ministers of the Indian Ocean Rim Association (IORA)". 18 October 2017. $<$ https://www.gov.za/speeches/communiqu\%C3\%A9-17th-meeting-council-ministers-indian-ocean-rim-association-18-oct-2017-0000> Accessed on 24 April 2019.

123 DIRCO public information op. cit.

124 South African Government. "Minister Lindiwe Sisulu: Council of Ministers Meeting of Indian Ocean Rim Association". 2 November 2018. $<\underline{\text { https:// }}$ www.gov.za/speeches/iora-council-ministers-meeting-2-nov-2018-0000> Accessed on 24 April 2019.

125 South African Government. "Minister Maite Nkoana-Mashabane: Concluding remarks at Indian Ocean Rim Association Meeting of Council of Ministers". 18 October 2017. < https:/www.gov.za/speeches/minister-maite-nkoana-mashabane-indian-ocean-rim-association-17th-meeting-council-ministers $>$ Accessed on 24 April 2019.

126 South African Government. "Minister Lindiwe Sisulu ..." op. cit. 127 Ibid. 
128 South African Government. "Minister Maite Nkoana-Mashabane: Opening remarks ..." op. cit.

129 South African Government. "Deputy Minister Luwellyn Landers: Indian Ocean Conference”. 28 August 2018. < https://www.gov.za/speeches/address-deputy-minister-landers-indian-ocean-conference- $\%$ E2\%80\% $\%$ Cbuilding-regional-architecture $\% \mathrm{E} 2 \% 80 \% 9 \mathrm{D}-28>$ Accessed on 24 April 2019.

130 Ibid.

131 Ibid.

132 See Benguela Current Commission. "The Benguela Current Convention” (BCC). 2013. <https://www.benguelacc.org/index.php/en/about/the-benguela-current-convention $>$ Accessed on 26 April 2019.

133 See article 2 of the BCC.

${ }^{134}$ Molewa op. cit. The last annual report published on the $\mathrm{BCC}$ website dates from 2017. An assessment of the implementation of Minister Molewa's remarks at the $6^{\text {th }}$ Ministerial Conference of the BCC could be made upon the release of the 2018-2019 report. See Benguela Current Commission. "Publications". 2013. <https://www.benguelacc.org/index.php/en/publications $>$ Accessed on 1 February 2020.

${ }^{135}$ A Lalbahadur, N Grobbelaar \& R du Plessis. "South Africa's foreign policy priorities for the 21st century: A closer look at the potential for co-operation in the South Atlantic zone". South African Institute of International Affairs. 19 May 2015. <https://saiia.org.za/research/south-africas-foreign-policy-priorities-for-the-21st-century-a-closer-look-at-the-potential-for-co-operationin-the-south-atlantic-zone-2/> Accessed on 24 April 2019.

136 This includes the largest and most significant economies of sub-Saharan Africa and Latin America.

${ }^{137}$ United Nations General Assembly. "Zone of Peace and Cooperation of the South Atlantic”. Report of the Secretary-General. UN Doc. A/50/671. 24 October 1995 at par II (D).

${ }^{138}$ Lalbahadur et al. op. cit.

139 Ibid.

140 Ibid.

141 Ibid.

142 South African Government. "Statement on the Cabinet Meeting". 1 November 2017. <https://www.gov.za/speeches/statement-cabinet-meeting-wednesday1-november-2017-2-nov-2017-0000>Accessed on 24 April 2019.

143 South African Government. "Deputy Minister Sindisiwe Chikunga briefs media on South Africa's bid for re-election to the United Nations IMO Council". 22 November 2017. <https://www.gov.za/speeches/deputy-minister-sindisiwe-chikunga-briefs-media-south-africa $\%$ E2\%80\%99s-bid-re-election-united> Accessed on 24 April 2019. 
${ }^{144}$ South African Government. "Deputy Minister Sindisiwe Chikunga addresses 30th regular session of IMO and congratulates newly elected officers". 29 November 2017. $<$ https://www.gov.za/speeches/deputy-minister-sindisiwe-chikunga-addresses-30th-regular-session-imo-and-congratulates $>$ Accessed on 24 April 2019.

${ }^{145}$ South African Government. "Deputy Minister Sindisiwe Chikunga: International Maritime Organisation". 28 November 2017. $<$ https://www. gov.za/speeches/deputy-minister-sindisiwe-chikunga-international-maritime-organisation-28-nov-2017-0000>Accessed on 24 April 2019.

${ }^{146}$ Ibid.

${ }^{147}$ Ibid.

${ }^{148}$ Ibid.

${ }^{149}$ South African Government. "South Africa re-elected to the IMO Council". 3 December 2017. <https://www.gov.za/speeches/south-africa-re-electedinternational-maritime-organisation-2018-2019-period-3-dec-2017> Accessed on 24 April 2019.

${ }^{150}$ NPC op. cit., p. 238.

${ }^{151}$ South African Government. "Minister Blade Nzimande: Inaugural Maritime Transport Dialogue". 28 February 2019. $<$ https://www.gov.za/ speeches/minister-blade-nzimande-inaugural-maritime-transport-dialogue-28-feb-2019-0000>Accessed on 24 April 2019.

${ }^{152}$ South African Government. "Science and Technology invests in Maritime Domain Awareness Satellite programme". 26 February 2019. $<$ https://www. gov.za/node/787034> Accessed on 24 April 2019.

${ }^{153}$ Ibid.

${ }^{154}$ Ibid.

${ }^{155}$ South African Government. "President Jacob Zuma: Update on implementation of Operation Phakisa: Oceans Economy Programme". 6 October 2017. $<$ https://www.gov.za/speeches/president-jacob-zuma-update-implementation-operation-phakisa-oceans-economy-programme-6-oct> Accessed on 24 April 2019.

${ }^{156}$ South African Government. "Minister Maite Nkoana-Mashabane: Opening remarks ..." op. cit.

157 Ibid.

${ }^{158}$ PM Haas. "Evaluating the effectiveness of marine governance". In Thia-Eng, C et al. (eds), Securing the oceans: Essays on ocean governance: Global and regional perspectives. Quezon City: Partnerships in Environmental Management for the Seas of East Asia, 2008, 267.

${ }^{159}$ South African Government. "Minister Maite Nkoana-Mashabane: Closing remarks...”op. cit. 
${ }^{160}$ Benkenstein op. cit., p. 3.

161 Judgment of the court is reported as Sahrawi Arab Democratic Republic and An other v Owner and Charterers of the MV 'Cherry Blossom' and Others 2017 (5) SA 105 (ECP).

162 Ibid., par [13].

${ }^{163}$ R Munusamy. “Quicksands of diplomacy”. Sunday Times. 14 April 2019. 16.

164 Ibid.

${ }^{165}$ Indian Ocean Rim Association (IORA). "Ninth Bi-annual Meeting of the Committee of Senior Officials 19-20 June 2019”. 2019. <https://www.iora. int/en/events-media-news/news-updates-folder/ninth-bi-annual-meetingof-the-committee-of-senior-officials-cso-19-20-june-2019>Accessed on 24 April 2019.

166 Ibid.

167 Department of International Relations and Cooperation. "Minister Pandor to attend the 19th IORA Council of Ministers Meeting and hand over SA's report as Chair of IORA". 6 November 2019 <http://www.dirco.gov.za/docs/2019/ iora1106.htm $>$ Accessed on 1 March 2020.

168 IORA. "IORA 20th Commemorative Leaders' Summit". 2017. $<$ https://www.iora.int/en/events-media-news/events/other/20th-leaders-summit/2017/iora-20th-commemorative-leaders-summit $>$ Accessed on 24 April 2019.

169 Ibid.

${ }^{170}$ Indian Ocean Rim Association. "Jakarta Concord: Promoting Regional Cooperation for a Peaceful, Stable and Prosperous Indian Ocean”. 2017. $<$ https://www.iora.int/media/23699/jakarta-concord-7-march-2017.pdf $>$ Accessed on 1 March 2020.

${ }^{171}$ Ibid. South Africa was at the forefront of drafting the IORA Concord's Action Plan (2017 - 2021) which provides a firm set of realistic and measurable commitments. See: M Mokoena (ed). "International Relations". South Africa Yearbook. 2018/19. Pretoria: Department of Government Communications and Information Systems at 11.

172 J Anand, diplomat and researcher: Asia and Middle East Branch: Department of International Relations and Cooperation, personal interview, Umhlanga Ridge, Durban, 20 June 2019.

173 Ibid.

${ }^{174}$ Du Plessis op. cit., p. 48.

175 Benkenstein op. cit.

176 Ibid.

${ }^{177}$ Lalbahadur \& Du Plessis op. cit. 
178 South African Government. "Foreign Policy for South Africa ..." op. cit., p. 6. [Is this the source you mean? Yes]

${ }^{179}$ N Grobbelaar. "South Africa's ambitious foreign policy". South African Institute of International Affairs. 2 June 2011. < $\underline{\text { https://saiia.org.za/research/south-af- }}$ ricas-ambitious-foreign-policy/> Accessed on 24 April 2019.

180 South African Government. "Foreign Policy for South Africa ..." op. cit. [Is this the source you mean? Yes]

181 Ibid.

182 NPC op. cit., p. 237.

${ }^{183}$ A Kelafe, M Schoeman \& C Alden. 'It's time South Africa turned into Africa's views". South African Institute of International Affairs. 25 January 2017. $<$ https://saiia.org.za/research/its-time-south-africa-tuned-into-africas-viewsabout-its-role-on-the-continent/>Accessed on 24 April 2019.

184 Ibid.

185 Ibid.

186 Ibid. 